\title{
Brain muscarinic cholinergic receptors in Huntington's disease
}

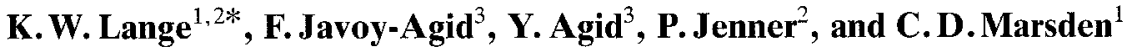 \\ ${ }^{1}$ University Department of Clinical Neurology, Institute of Neurology and The National Hospital for Neurology and Neurosurgery, \\ London, UK \\ ${ }^{2}$ Pharmacology Group, Biomedical Sciences Division, King's College, London, UK \\ ${ }^{3}$ Laboratoire de Médicine Expérimentale, INSERM U. 289, Hôpital de la Salpêtrière, Paris, France
}

Received March 15, 1991 / Received in revised form May 10, 1991 / Accepted May 16, 1991

Summary. Muscarinic cholinergic receptors and choline acetyltransferase (ChAT) activity were studied in postmortem brain tissue from patients with Huntington's disease and matched control subjects. In comparison with controls, reductions in ChAT activity were found in the hippocampus, but not in the temporal cortex in Huntington's disease. Patients with Huntington's disease showed reduced densities of the total number of muscarinic receptors and of $\mathrm{M}-2$ receptors in the hippocampus while the density of M-1 receptors was unaltered. Muscarinic receptor binding was unchanged in the temporal cortex. These results indicate a degeneration in Huntington's disease of the septo-hippocampal cholinergic pathway, but no impairment of the innominato-cortical cholinergic system.

Key words: Acetylcholine - Choline acetyltransferase Muscarinic receptors - Huntington's disease

\section{Introduction}

Huntington's disease is characterized clinically by choreiform movements and progressive dementia. Dementia in Alzheimer's disease and Parkinson's disease appears to be associated with degeneration of subcortico-cortical cholinergic systems $[5,7,9]$. While acetylcholine-containing neurons are damaged in the basal ganglia in Huntington's disease $[2,10]$, the status of the cholinergic afferent projections to the neocortex and hippocampus is less clear. We have examined choline acetyltransferase (ChAT) activity and muscarinic cholinergic receptor binding in the temporal cortex (Brodmann area 38) and hippocampus in Huntington's disease.

\section{Patients and methods}

Brain tissue was obtained at autopsy from 12 patients with neuropathologically confirmed Huntington's disease and from 12 matched

* Present address and address for offprint requests: UniversitätsNervenklinik, Füchsleinstrasse 15, W-8700 Würzburg, Federal Republic of Germany control subjects with no evidence of neurological or psychiatric disease. All patients with Huntington's chorea had suffered from advanced forms of the disease and had been demented according to DSM III criteria [1]. They had received neuroleptic medication up to the time of death. Controls had not received any drugs that are known to affect the central nervous system. Using washed membrane homogenates, saturation analysis was performed for the total number of muscarinic receptors with $\left[{ }^{3} \mathrm{H}\right]$-quinuclidinylbenzilate, for $\mathrm{M}-1$ receptors with $\left[{ }^{3} \mathrm{H}\right]$-pirenzepine and for $\mathrm{M}-2$ receptors with $\left[{ }^{3} \mathrm{H}\right]$-oxotremorine-M. Non-specific binding was defined by atropine. Protein concentration and ChAT activity were measured by standard techniques (details from K.W. L.).

\section{Results}

In comparison with controls, reductions in ChAT activity were found in the hippocampus but not in the tem-

Table 1. Mean (SEM) ChAT activity and maximal receptor binding in the temporal cortex and hippocampus. $* P<0.05$ (Wilcoxon's rank-sum test); ChAT activity in $\mathrm{nmol} / \mathrm{h} / \mathrm{mg}$ protein; receptor binding as $B_{\max }$ in $\mathrm{fmol} / \mathrm{mg}$ protein

\begin{tabular}{lll}
\hline & Control & $\begin{array}{l}\text { Huntington's } \\
\text { disease }\end{array}$ \\
\hline No. of brains & 12 & 12 \\
Sex & $2 \mathrm{~F}, 10 \mathrm{M}$ & $5 \mathrm{~F}, 7 \mathrm{M}$ \\
Age (years) & $68.7(2.5)$ & $64.2(2.1)$ \\
Death to brain removal (h) & $28.4(5.6)$ & $30.1(4.4)$ \\
ChAT activity & & \\
$\quad-$ in temporal cortex & $4.5(0.3)$ & $4.2(0.3)$ \\
$\quad$ - in hippocampus & $12.7(0.9)$ & $8.1(0.8)^{*}$ \\
{$\left[{ }^{3} \mathrm{H}\right]$-quinuclidinylbenzilate binding } & & \\
$\quad-$ in temporal cortex & $861(32)$ & $811(26)$ \\
$\quad$ - in hippocampus & $364(12)$ & $280(12)^{*}$ \\
{$\left[{ }^{3} \mathrm{H}\right]$-pirenzepine binding } & & \\
$\quad-$ in temporal cortex & & \\
$\quad$ - in hippocampus & $651(20)$ & $580(18)$ \\
{$\left[{ }^{3} \mathrm{H}\right]$-oxotremorine-M-binding } & $235(13)$ & $197(15)$ \\
$\quad-$ in temporal cortex & & \\
- in hippocampus & $183(12)$ & $194(10)$ \\
\hline
\end{tabular}


poral cortex in Huntington's disease (Table 1). Patients with Huntington's disease showed reduced densites of the total number of muscarinic receptors and of M-2 receptors measured by specific binding of $\left[{ }^{3} \mathrm{H}\right]$-quinuclidinylbenzilate and $\left[{ }^{3} \mathrm{H}\right]$-oxotremorine- $\mathrm{M}$ in the hippocampus while the density of M-1 receptors, as identified by specific $\left[{ }^{3} \mathrm{H}\right]$-pirenzepine binding, was unchanged. Muscarinic receptor binding was unaltered in the temporal cortex. Alterations in the equilibrium dissociation constants $\left(\mathrm{K}_{\mathrm{D}}\right)$ were not observed.

\section{Discussion}

The reduction in ChAT activity and in muscarinic M-2 receptors, which are thought to be located mainly presynaptically, indicates a degeneration of the cholinergic pathway from the septum to the hippocampus. This is supported by decreased ChAT activity in septal nuclei [10]. The present results of unaltered cortical ChAT activity and putatively pre-synaptic $\mathrm{M}-2$ receptors suggest that the ascending cholinergic system from the substantia innominata to the neocortex is not damaged in Huntington's disease. This is consistent with previous reports showing a preservation of neurons in the nucleus basalis of Meynert [3,6]. Dementia is associated with neuronal damage or loss in the nucleus basalis in Alzheimer's disease and Parkinson's disease [8]. The findings in Huntington's disease, however, indicate that damage to this region is not a prerequisite for the development of dementia. The cognitive impairment in Huntington's disease may be related to hippocampal deficits and damage to neuronal systems within the basal ganglia, although it cannot be ruled out that the dementia might stem directly from cortical atrophy [4].
Acknowledgement. This study was supported by the Medical Research Council and the Parkinson's Disease Society. K. W. L. was supported by the Deutsche Forschungsgemeinschaft.

\section{References}

1. American Psychiatric Association (1980) Diagnostic and statistical manual of mental disorders, 3 rd edn. American Psychiatric Association, Washington, DC

2. Bird ED, Iversen LL (1974) Huntington's chorea: post-mortem measurement of glutamic acid decarboxylase, choline acetytransferase and dopamine in basal ganglia. Brain 97:457472

3. Clark AW, Parhard IM, Folstein SE, et al (1983) The nucleus basalis in Huntington's disease. Neurology 33:1262-1267

4. Kuwert T, Lange HW, Langen K-J, Herzog H, Aulich A, Feinendegen LE (1990) Cortical and subcortical glucose consumption measured by PET in patients with Huntington's disease. Brain 113:1405-1423

5. Lange KW, Wells FR, Rossor MN, Jenner P, Marsden CD (1989) Brain muscarinic receptors in Alzheimer's disease and Parkinson's disease. Lancet II : 1279

6. Mann DMA (1989) Subcortical affarent projection systems in Huntington's chroea. Acta Neuropathol (Berl) 78:551-554

7. Perry EK, Tomlinson BE, Blessed G, Bergmann K, Gibson PH, Perry RH (1978) Correlation of cholinergic abnormalities with senile plaques and mental test scores in senile damentia. BMJ II: 1457-1459

8. Perry EK, Curtis M, Dick DJ, et al (1985) Cholinergic correlates of cognitive impairment in Parkinson's disease: comparison with Alzheimer's disease. J Neurol Neurosurg Psychiatry 48:413-421

9. Ruberg M, Ploska A, Javoy-Agid F, Agid Y (1982) Muscarinic binding and choline acetyltransferase activity in Parkinsonian subjects with reference to dementia. Brain Res 232:129-139

10. Spokes EGS (1980) Neurochemical alterations in Huntington's chorea: a study of post-mortem brain tissue. Brain 103:179210 